\title{
A new model of how celebrity endorsements work: attitude toward the endorsement as a mediator of celebrity source and endorsement effects
}

\section{Lars Bergkvist, Hanna Hjalmarson \& Anne W. Mägi}

To cite this article: Lars Bergkvist, Hanna Hjalmarson \& Anne W. Mägi (2016) A new model of how celebrity endorsements work: attitude toward the endorsement as a mediator of celebrity source and endorsement effects, International Journal of Advertising, 35:2, 171-184

To link to this article: http://dx.doi.org/10.1080/02650487.2015.1024384

曲 Published online: 07 Apr 2015.

Submit your article to this journal $₫$

Џll Article views: 389

Q View related articles $\sqsubset$

View Crossmark data ¿ 


\title{
A new model of how celebrity endorsements work: attitude toward the endorsement as a mediator of celebrity source and endorsement effects
}

\author{
Lars Bergkvist (10 ${ }^{a *}$, Hanna Hjalmarson ${ }^{\mathrm{b}}$ and Anne W. Mägi ${ }^{\mathrm{c}}$ \\ ${ }^{a}$ University of Nottingham Ningbo, Nottingham University Business School, Ningbo, China; \\ ${ }^{b}$ Stockholm University, Stockholm Business School, Stockholm, Sweden; ${ }^{c}$ Department of \\ Managerial Studies, University of Illinois at Chicago, Chicago, USA
}

(Received 1 September 2013; accepted 24 February 2015)

\begin{abstract}
This research introduces attitude towards the endorsement as a mediating variable in the relationships between celebrity source and endorsement factors and brand attitude. It also includes perceived celebrity motive, a variable rarely studied in the previous literature, as an endorsement factor. In a survey study, respondents evaluated four celebrity endorsement campaigns. Mediation analyses show that attitude towards the endorsement mediates the effects of three variables on brand attitude; these variables are celebrity expertise, celebrity-brand fit, and perceived celebrity motive. Moreover, results show that if consumers perceive that the celebrity was motivated to do the endorsement not only by money but also by product quality, this has a significant positive effect on attitude towards the brand.
\end{abstract}

Keywords: advertising; marketing communications; celebrity endorsements; brand attitude; mediation analysis

\section{Introduction}

Celebrity endorsement is a common advertising strategy: a recent content analysis found that $10 \%$ of US magazine ads featured a celebrity (Belch and Belch 2013). Companies today spend significant amounts of money on celebrity endorsements. For example, Nike's endorsement contracts were worth more than US \$800 million in 2013 (Nike 2012). This trend has spurred research to examine if and how using celebrities affects brand attitude $\left(\mathrm{A}_{\mathrm{BRAND}}\right)$ and behaviour towards the brand. Studies have explored a range of source factors, including those focusing on general characteristics of the celebrity in question, such as attractiveness and likability (e.g., Kahle and Homer 1985), and endorsement factors that implicitly or explicitly centre on the celebrity's role as spokesperson for a particular product, such as product category expertise (e.g., Rossiter and Smidts 2012) and celebrity-brand fit (e.g., Lee and Thorson 2008).

This study aims to provide a better understanding of the processes underlying celebrity endorsements by introducing a new variable - attitude towards the endorsement $\left(\mathrm{A}_{\text {ENDORSEMENT }}\right)$ - as a mediator between previously studied source and endorsement factors and $A_{B R A N D}$. From a theoretical perspective, it is of relevance to understand whether there is a direct link between the various determinants included in previous studies and $A_{\text {BRAND, }}$, or whether these source and endorsement factors initially lead to an overall assessment of the endorsement and this assessment in turn leads to a positive

*Corresponding author. Email: lars.bergkvist@yahoo.se 
evaluation of the brand. From a practical perspective, if the effects of source variables previously studied are mediated by $\mathrm{A}_{\text {ENDORSEMENT }}$, it may often be sufficient to measure this latter variable when evaluating the efficacy of celebrity endorsements.

In addition to a selection of previously studied source and endorsement factors, the study also includes perceived celebrity motive as an endorsement factor that theory and research in related areas suggest is relevant in a celebrity endorsement context (e.g., Barone, Miyazaki, and Taylor 2000; Chang 2012; Ruth and Strizhakova 2012). It seems reasonable that consumers either consciously or subconsciously make attributions about why a certain celebrity endorses a certain brand, which would influence the effectiveness of the endorsement.

\section{Theoretical background and hypotheses}

Figure 1 shows the proposed effects of source and endorsement factors on $A_{\text {BRAND }}$ and, in particular, how $A_{\text {ENDORSEMENT }}$ is hypothesized to mediate the effects of antecedent variables. These relationships are based on previous research on celebrity endorsements, research in the related areas of sponsorships, cause-related marketing (CRM), product placement, and brand alliances, and attitude theory. The following sections present the rationales for the hypothesized relationships.

\subsection{Attitude towards the celebrity}

People form attitudes towards a broad range of objects (Ajzen 1988), and celebrities are no exception (Luo et al. 2010). Following mainstream definitions of attitude (Ajzen 1988, $4)$, we define attitude towards a celebrity $\left(\mathrm{A}_{\text {Celebrity }}\right)$ as someone's positive or negative evaluation (like or dislike) of the celebrity in question. This construct has been included in a number of celebrity endorsement studies, sometimes labeled as celebrity liking, celebrity likability, or celebrity affect, and these studies tend to find a positive

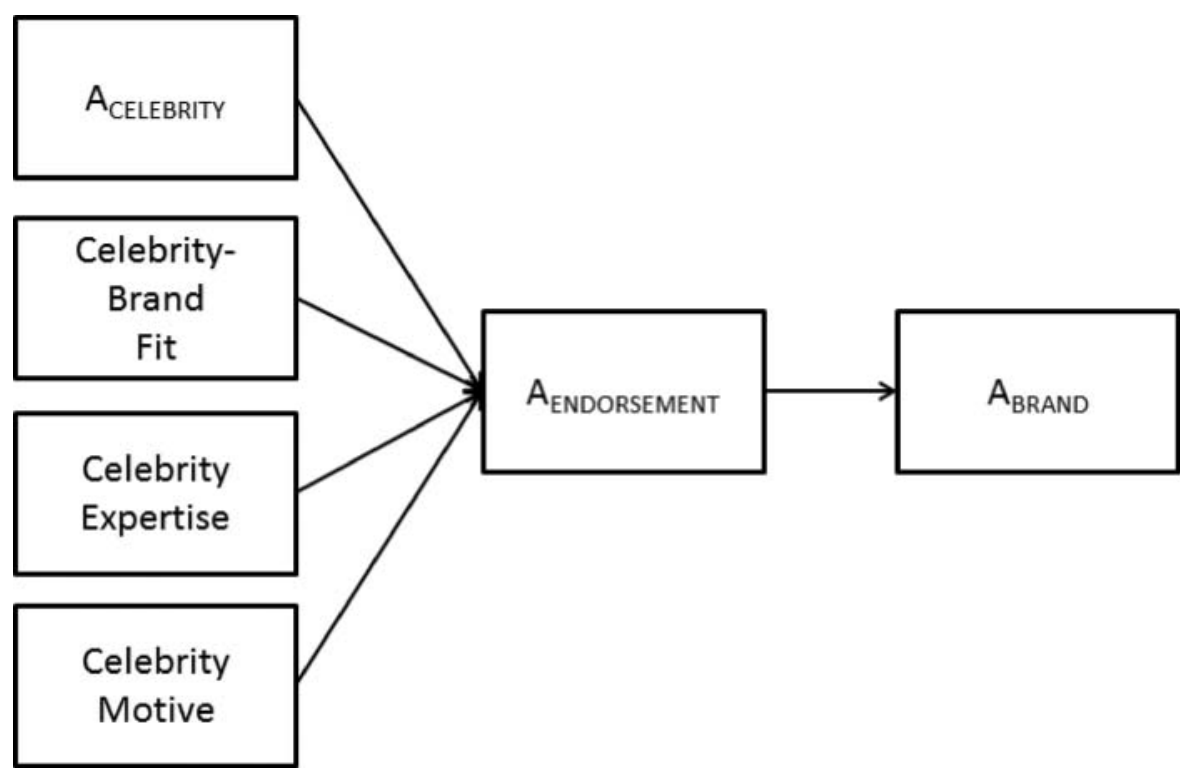

Figure 1. Conceptual model of the effects of celebrity and endorsement factors on $A_{B R A N D}$. 
relationship between $A_{\text {Celebrity }}$ and $A_{\text {Brand }}$ (e.g., Amos, Holmes, and Strutton 2008; Kahle and Homer 1985; Silvera and Austad 2004). Results in related areas provide further support for the notion of a positive relationship between $A_{\text {CELEBRITy }}$ and $A_{B R A N D}$ : Olson (2010) finds a positive relationship between attitude towards the sponsored object and $\mathrm{A}_{\text {BRAND; }}$ Schemer et al. (2008) discover that attitude towards the artist in a music video transfers to a brand placed in the video; and Basil and Herr (2006) and Lafferty, Goldsmith, and Hult (2004) find a positive relationship between attitude towards the non-profit organization in a CRM alliance and $\mathrm{A}_{\mathrm{BRAND}}$.

H1a: There is a positive relationship between $A_{\text {CELEBRITY }}$ and $A_{\text {BRAND. }}$

\subsection{Celebrity-brand fit}

The fit between the celebrity and the brand has been the focus of a number of studies of celebrity endorsements (e.g., Fleck, Korchia, and Le Roy 2012; Garcia de los Salmones, Dominguez, and Herrero 2013; Kahle and Homer 1985). Fit, which has also been called congruency, similarity, and relevance, has its marketing origins in the brand extension literature where it refers to the degree of similarity or consistency between the parent brand and the brand extension (Aaker and Keller 1990). In the celebrity endorsement literature, fit typically refers to the similarity or consistency between the brand and the celebrity, and as such, this variable is specific to a particular endorsement situation. Several celebrity endorsement studies have shown that fit has a positive effect on $A_{\text {BRAND }}$ (e.g., Amos, Holmes, and Strutton 2008; Choi and Rifon 2012; Kirmani and Shiv 1998), and similar results have been found in studies of sponsorship (e.g., Olson 2010; Speed and Thompson 2000), CRM (e.g., Lafferty, Goldsmith, and Hult 2004), and brand alliances (Simonin and Ruth 1998). The theoretical argument for why fit is important is that perceived lack of fit between the celebrity and the brand leads to negative attributions which, in turn, lead to negative brand evaluation effects (Lafferty 2009; Simonin and Ruth 1998). Thus, exposure to a low-fit celebrity endorsement generates negative cognitions, which, in turn, have a negative effect on brand evaluations.

H1b: There is a positive relationship between celebrity-brand fit and $A_{B R A N D}$.

Some studies have included fit as a moderator of the effects of celebrity endorsements on $A_{\text {BRAND }}$ (e.g., Misra and Beatty 1990). This relationship is sometimes referred to as the match-up hypothesis (e.g., Kamins 1990). However, the evidence supporting this relationship is mixed. Some studies have found a statistically significant moderating relationship (e.g., Misra and Beatty 1990), while other studies merely have found a 'marginally significant' relationship (e.g., Kamins 1990; Kamins and Gupta 1994). Since there is a fair amount of empirical support for fit as a main effect, only a few studies support fit as a moderator, and some studies do not support fit as a moderator, we decided to include celebrity-brand fit as a main effect on $A_{\text {BRAND }}$ rather than a moderator. While we do not rule out that fit can moderate the effects of celebrity endorsement on brand evaluations, we do believe that a conceptualization with fit as a main effect on $A_{\text {BRAND }}$, mediated by $\mathrm{A}_{\text {ENDORSEMENT }}$ (see below), has stronger support in previous research and theory.

\subsection{Celebrity expertise}

Expertise is one of two dimensions of source credibility in the classic source credibility model (the other dimension is trustworthiness), which argues that communication from a 
high-credibility source has greater persuasive effects than communication from a lowcredibility source (Hovland, Janis, and Kelley 1953; also see overview in Ohanian 1990). Hovland, Janis, and Kelley $(1953,21)$ define source expertise as 'the extent to which a communicator is perceived to be a source of valid assertions'. According to the original source credibility model, credible sources have both direct effects on people's willingness to accept messages and indirect effects on attention and comprehension (Eagly and Chaiken 1993, 259-60). Moreover, research based on the Heuristic-Systematic model (Chaiken 1980) has found that cues such as expert sources trigger the use of rules such as 'experts' statements can be trusted', a heuristic that has been demonstrated in a marketing context (Ratneshwar and Chaiken 1991). In a celebrity endorsement context, celebrity expertise has been shown to have a positive effect on $A_{\text {BRAND }}$ (Eisend and Langner 2010), purchase intention (Ohanian 1991), and product evaluations (Rossiter and Smidts 2012). In line with this, we argue that celebrity expertise has a positive effect on $A_{B R A N D}$.

H1c: There is a positive relationship between celebrity expertise and $A_{B R A N D}$.

In contrast with $\mathrm{A}_{\mathrm{CELEBRITY}}$, source expertise is context specific. For example, it can be assumed that Tiger Woods has more expertise with sports apparel (Nike) than with consulting services (Accenture). Thus, a celebrity endorser's expertise has to be evaluated for each endorsement situation, and it cannot be assumed that a celebrity has high or low expertise across product categories. With respect to the other dimension of the original source credibility model, trustworthiness, results in previous research are mixed. Rossiter and Smidts (2012) hypothesized that trustworthiness is not relevant for celebrity endorsers but, contrary to their hypothesis, their results showed a negative effect of lack of trust (although there was no positive effect of high trust). However, Ohanian (1991) found no effect of celebrity trustworthiness on $A_{B R A N D}$ at the same time as there was a positive effect for celebrity expertise. In light of the weak or non-existent support for a positive effect of celebrity trustworthiness in previous research, this variable was not included in the present study.

\subsection{Perceived celebrity motive}

A potentially important factor in celebrity endorsements is consumers' attribution of motives for the celebrity's endorsement. Attribution theory states that people tend to perceive causes for other people's actions, and these perceptions influence behaviour, affect, and expectancy (see overview in Kelley and Michela 1980). Thus, if a celebrity is attributed mainly negative motives for making a brand endorsement, this is likely to have a negative effect on brand evaluations. For example, if the celebrity is seen as mainly motivated by monetary incentives, as opposed to actual use and/or liking of the product, this may have a negative effect on brand evaluations.

The celebrity's motive for endorsing a brand as a possible determinant of $A_{\text {BRAND }}$ has received scant research attention, and there appears to be no quantitative study of this factor. However, qualitative results in Tripp, Jensen, and Carlson (1994) suggest that consumers' perceptions that celebrities are motivated primarily by money negatively affect their brand evaluations. Similarly, Moore, Mowen, and Reardon (1994) find a negative effect of paid (vs. unpaid) non-celebrity product endorsers on $A_{\text {BRAND. Moreover, }}$ research on sponsorship and CRM has demonstrated the importance of attribution of motives. These studies show that the attribution of positive motives (e.g., making a positive contribution to society) leads to a positive effect on brand evaluations, and that the attribution of negative motives (e.g., the only motive is making money) has a negative effect on brand evaluations (Ruth and Simonin 2006; Speed and Thompson 2000). In line with this, we expect attribution of positive motives to have a positive effect on $A_{B R A N D}$. 
H1d: There is a positive relationship between perceived positive celebrity motives and $A_{\text {BRAND. }}$

\subsection{Attitude towards the endorsement as a mediator of endorsement variables}

Previous studies of source factors have assumed a direct effect of these variables on attitude towards the brand. However, based on findings in related areas of research such as sponsorships and CRM (e.g., Barone, Miyazaki, and Taylor 2000; Ruth and Strizhakova 2012), these effects may be mediated. Research in the area of CRM has found that consumers form an attitude towards the alliance between the brand and the non-profit organization, and that this attitude mediates the effects of CRM variables (e.g., fit and attitude towards the non-profit organization) on $A_{\text {BRAND }}$ (Lafferty, Goldsmith, and Hult 2004). Similar results have been obtained for sponsorships (e.g., Olson 2010) and brand alliances (Simonin and Ruth 1998). We suggest that consumers also form an attitude towards the celebrity-brand alliance in a celebrity endorsement that may similarly function as a mediator. For example, a consumer may like Tiger Woods's endorsement of Nike products but be indifferent to or dislike his endorsement of Accenture. Following attitude theory (e.g., Ajzen 1988), we define A AnDORSEMENT as the overall positive or negative evaluation of the alliance between the celebrity and the brand in a particular celebrity endorsement relationship.

There is also a theoretical argument to be made for the mediating effects of A ENDORSEMENT. Research shows that exposure to a celebrity endorsement triggers endorsement-related cognitive responses in consumers (Mehta 1994), and a study of sponsorship found similar results (Simmons and Becker-Olsen 2006). These cognitions should function in a similar way as cognitions during and following advertising exposure (see Wright 1973). Thus, we expect that endorsement-related cognitions influence $A_{E N-}$ DORSEMENT in the same way that ad-related cognitions influence attitude towards the ad (MacKenzie, Lutz, and Belch 1986). For example, a consumer's liking of the celebrity, perception of a good fit between the brand and the celebrity, beliefs that the celebrity has expertise in the product category, and attributions about a positive motive to the celebrity's endorsement, are positive cognitions that will have a positive effect on $A_{\text {ENDORSE- }}$ MENT which, in turn, will have a positive effect on brand attitude.

H2: $A_{\text {Endorsement }}$ mediates the effects of $A_{\text {CELEBrity }}(\mathrm{H} 2 \mathrm{a})$, celebrity-brand fit $(\mathrm{H} 2 \mathrm{~b})$, celebrity expertise (H2c), and perceived celebrity motive (H2d) on $A_{\text {BRAND. }}$.

\section{Research design}

This research is based on a survey of young women who evaluated four ongoing or recent advertising campaigns featuring celebrities. Because our goal was to capture the longterm effects of celebrity endorsements, we deemed it more appropriate to conduct a survey on existing ads rather than a laboratory experiment with unfamiliar brands paired with celebrities in mock ads, as in previous celebrity endorsement research (e.g., Eisend and Langner 2010; Kahle and Homer 1985). By studying real campaigns, we avoided the 'temporal myopia' of laboratory experiments that tend to study 'short-run answers to short-run stimuli' (Laurent 2013, 323). Instead, we captured the accumulated effect of exposure to the campaigns over a longer term. By doing this, we avoid two problems. First, we capture consumer response after exposure to the campaign rather than immediately following forced exposure in an experimental setting. A study by Bergkvist and Rossiter (2008) found that the long-term consumer response after a campaign is different 
Table 1. Campaigns included in the study.

\begin{tabular}{lllll}
\hline Brand & Product category & Celebrity & Occupation & Campaign started \\
\hline Scorett & Shoe retailer & Carolina Gynning & TV personality & March 2010 \\
Oral-B & Electric toothbrush & Charlotte Kalla & Cross-country skier & October 2010 \\
Lätta & Low-fat margarine & Emma Wiklund & Retired Supermodel & First campaign in 1982 \\
Garnier & Hair products & Pernilla Wahlgren & Singer & January 2007 \\
\hline
\end{tabular}

from the short-term response in an experimental setting. Moreover, it has been shown that consumer response to advertising and celebrity endorsements is different when measurement is done with a delay rather than immediately following exposure (Chattopadhyay and Nedungadi 1992; Eisend and Langner 2010).

\subsection{Campaigns}

We selected four advertising campaigns that featured the endorsement of the advertised brand by a celebrity (Table 1). The campaigns had run for at least 2 years and were still running at the time of the study, except for the Lätta campaign, which has run intermittently, with the same celebrity, since 1982 but was not 'on air' during data collection. The four celebrities included in the study were Swedish women of varying fame. Including four campaigns in the study reduces the likelihood that individual campaign idiosyncrasies dominate the results of the study.

We chose the four campaigns to be similar with respect to target audience and message strategy, and to feature endorsers of the same gender and similar age. This was motivated by a desire to reduce extraneous variance. For example, previous research has shown gender differences in celebrity endorsement effects (Bush, Martin, and Bush 2004; Freiden 1984). Thus, the campaigns were chosen to be similar with respect to the celebrity's gender and the target audience. The selected campaigns targeted young women, and the message strategy was based on the transformational purchase motive of social approval (Rossiter and Percy 1997).

All brands were familiar to the participants and had been available on the Swedish market for many years. Consequently, the majority of participants recognized the ads and the celebrities, with only minor variation across the four ads (see Table 2).

Verified recognition of the celebrity, measured by an open-ended question that asked participants to write down the name of the celebrity in the ad, filtered out participants who were not familiar with the celebrity in question. Thus, the analyses included only the participants who could identify the celebrity in the ad (filtering on ad recognition rather than verified celebrity recognition yielded virtually identical results in the analysis).

\subsection{Participants}

The study is based on a survey of 199 female consumers between the ages of 17 and 30 . This age group was chosen as it matched the target audience of the campaigns evaluated in the study. The sample was split in two, with each half evaluating two campaigns to avoid respondent fatigue. There were no significant demographic differences between the two sample groups. We rotated the order in which the campaigns were evaluated between the questionnaires and, accordingly, there were two versions of each questionnaire. We 
Table 2. Brand familiarity, and ad and celebrity recognition.

\begin{tabular}{lcccr}
\hline Measure and response alternatives & $\begin{array}{c}\text { Oral-B } \\
\mathbf{( \% )}\end{array}$ & $\begin{array}{c}\text { Garnier } \\
\mathbf{( \% )}\end{array}$ & $\begin{array}{c}\text { Scorett } \\
\mathbf{( \% )}\end{array}$ & $\begin{array}{c}\text { Lätta } \\
\mathbf{( \% )}\end{array}$ \\
\hline Brand familiarity: & & & & \\
I have never seen or heard of it. & 0.0 & 1.0 & 0.0 & 1.0 \\
I have seen or heard of it once or on a few occasions. & 32.0 & 15.0 & 20.2 & 6.1 \\
I am familiar with this brand. & 50.0 & 56.0 & 50.5 & 43.4 \\
I am very familiar with this brand and I have used & 18.0 & 28.0 & 29.3 & 49.5 \\
$\quad$ it several times. & & & & \\
\hline Ad recognition: & 37.0 & 14.0 & 56.6 & 51.5 \\
No, never. & 27.0 & 31.0 & 27.3 & 37.4 \\
Yes, once or a few times. & 36.0 & 55.0 & 16.2 & 11.1 \\
Yes, several times. & & & & \\
\hline Claimed celebrity recognition: & 79.0 & 95.0 & 60.6 & 77.8 \\
Yes & 21.0 & 5.0 & 39.4 & 22.2 \\
No & & & & \\
\hline Verified celebrity recognition: & 75.0 & 94.0 & 56.6 & 74.7 \\
Correct & 25.0 & 6.0 & 43.4 & 25.3 \\
Incorrect/no answer & 100 & 100 & 99 & 99 \\
\hline$N$ & & & &
\end{tabular}

collected the data through a commercial web panel in Sweden (see Table 3 for details of the sample). Participants in the study were invited by the web panel operator to take part in the survey, and they responded online.

\subsection{Measures}

Because all constructs in the study were doubly concrete, we measured them with singleitem measures (Bergkvist and Rossiter 2007; see also Rossiter 2002, 2012). Doubly concrete constructs refer to "constructs for which both the object of measurement and the attribute of measurement are clear and unambiguous for those rating the object on the attribute' (Bergkvist and Rossiter 2009, 607-8). Typical examples of doubly concrete constructs are attitude towards the ad and $\mathrm{A}_{\mathrm{BRAND}}$ (Bergkvist in press; Bergkvist and Rossiter 2007, 2009). For the independent and dependent variables in the present study, the object of measurement is the brand $\left(\mathrm{A}_{\mathrm{BRAND}}\right)$, the celebrity $\left(\mathrm{A}_{\mathrm{CELEBRITY}}\right.$, celebrity expertise, perceived celebrity motive), or the combination of the brand and the celebrity (celebrity-brand fit, A ENDORSEMENT). Each of these refers to a specific instance (the brand or the celebrity in the campaign) or a combination of these two specific instances, and it is clear that the object of measurement in all cases is concrete. With respect to the attributes in the constructs, attitude ( $\mathrm{A}_{\text {CELEBRITY }}, \mathrm{A}_{\mathrm{BRAND}}, \mathrm{A}_{\text {ENDORSEMENT }}$ ), fit (celebrity-brand fit), expertise (celebrity expertise), and motive (perceived celebrity motive), the argument can in all cases be made that the attribute is concrete. It is well established 
Table 3. Study participant demographics and sample size.

\begin{tabular}{lc}
\hline Question & Mean (SD) \\
\hline Age range & 17 to 30 \\
Mean age & 23.3 \\
Gender: & \\
Women (\%) & 100 \\
Education: & \\
Compulsory school (\%) & 13 \\
High school (\%) & 49 \\
University (\%) & 34 \\
Other (\%) & 4 \\
Occupation: & \\
High school student (\%) & 13 \\
University student (\%) & 33 \\
Unemployed (\%) & 8 \\
Working (\%) & 38 \\
Other (\%) & 8 \\
$N$ & 199 \\
\hline
\end{tabular}

Note: SD: standard deviation.

that an attitude, in the sense of an overall evaluation, is concrete (Bergkvist in press; Bergkvist and Rossiter 2007, 2009; Rossiter 2002, 2011). Moreover, Rossiter (2011, $42-7$ ) argues that beliefs are always concrete as they have only one meaning to researchers as well as to people rating them. Since fit, expertise, and motive are all beliefs about objects, they fall into this category, and there are instances in previous research in which fit and expertise have been measured with single-item measures (e.g., Lafferty 2009; Rossiter and Smidts 2012; Walchli 2007).

The perceived motive of the celebrity measured whether participants perceived the celebrity as motivated by money, by the quality of the product, or a combination of the two. The category of 'money only' drew on the qualitative results in Tripp, Jensen, and Carlson (1994) and results from studies of attribution of motives in sponsorship and CRM (Ruth and Simonin 2006; Speed and Thompson 2000). The category of the 'quality of the product' was included as it is one of few obviously positive reasons for a celebrity to endorse a commercial product. (The positive motives explored in sponsorship and CRM research are not applicable in a celebrity endorsement context as they relate to doing good to society as a whole, or a specific part of it such as a particular sport.) In the analyses, we combined the two response alternatives, quality of the product and a combination of quality and money, into one category and coded the variable as dichotomous $(0=$ motivated only by money, $1=$ motivated at least partly by product quality), since there were not enough responses for separate analysis in the quality only category. Table 4 provides details of the measures.

We designed the questionnaire to minimize common methods variance (Podsakoff et al. 2003) by varying response scales and questionnaire layout. An evaluation using an approach from Malhotra, Kim, and Patil (2006) revealed negligible common method variance and no common methods bias. 
Table 4. The independent, mediating, and dependent variables in the study and their operationalizations.

\begin{tabular}{|c|c|c|c|}
\hline Construct & Question & Answer scale & Source \\
\hline $\mathrm{A}_{\text {CELEBRITY }}$ & $\begin{array}{l}\text { What do you think } \\
\text { about the following } \\
\text { celebrities? }\end{array}$ & $\begin{array}{l}\square \text { Dislike very much } \\
\square \text { Dislike fairly much } \\
\square \text { Neither dislike nor like } \\
\square \text { Like fairly much } \\
\square \text { Like very much }\end{array}$ & $\begin{array}{l}\text { Adapted from Bergkvist } \\
\text { and Rossiter (2007) }\end{array}$ \\
\hline$A_{\text {BRAND }}$ & $\begin{array}{l}\text { Thinking about the } \\
\text { [BRAND], which of } \\
\text { the following } \\
\text { statements best } \\
\text { describes your } \\
\text { feeling about it? }\end{array}$ & $\begin{array}{l}\square \text { I think it is extremely } \\
\text { good } \\
\square \text { I think it is quite good } \\
\square \text { I think it is slightly } \\
\text { good } \\
\square \text { I think it is neither } \\
\text { good nor bad } \\
\square \text { I think it is slightly bad } \\
\square \text { I think it is quite bad } \\
\square \text { I think it is extremely } \\
\text { bad }\end{array}$ & $\begin{array}{l}\text { Bergkvist and Rossiter } \\
\quad(2009)\end{array}$ \\
\hline A $_{\text {ENDORSEMENT }}$ & $\begin{array}{l}\text { What do you think } \\
\text { about } \\
\text { [CELEBRITY] } \\
\text { appearing in } \\
\text { advertising for } \\
\text { [BRAND]? }\end{array}$ & $\begin{array}{l}\text { 1. I dislike it very much } \\
2 . \\
3 . \\
4 . \\
5 . \\
\text { I like it very much }\end{array}$ & $\begin{array}{l}\text { Developed following } \\
\text { guidelines for attitude } \\
\text { measures in Rossiter } \\
(2011,86-7)\end{array}$ \\
\hline $\begin{array}{l}\text { Celebrity- } \\
\text { brand fit }\end{array}$ & $\begin{array}{l}\text { How well do you think } \\
\text { [CELEBRITY] fits } \\
\text { with [BRAND]? }\end{array}$ & $\begin{array}{l}\text { 1. Does not fit at all } \\
2 . \\
3 . \\
4 . \\
\text { 5. Fits very well together }\end{array}$ & $\begin{array}{l}\text { Adapted from single-item } \\
\text { fit measures in Lafferty } \\
(2009) \text { and Walchli } \\
(2007)\end{array}$ \\
\hline $\begin{array}{l}\text { Perceived } \\
\text { celebrity } \\
\text { motive }\end{array}$ & $\begin{array}{l}\text { Why do you think } \\
\text { [CELEBRITY] } \\
\text { appears in } \\
\text { advertising for } \\
\text { [BRAND]? }\end{array}$ & $\begin{array}{l}\square \text { Because [BRAND] has } \\
\text { good products } \\
\square \text { To make money } \\
\square \text { Both because } \\
\text { [BRAND] has good } \\
\text { products and to make } \\
\text { money }\end{array}$ & $\begin{array}{l}\text { Developed following } \\
\text { guidelines for } \\
\text { evaluative beliefs in } \\
\text { Rossiter }(2011,78-82)\end{array}$ \\
\hline $\begin{array}{l}\text { Celebrity } \\
\text { expertise }\end{array}$ & $\begin{array}{l}\text { How great knowledge } \\
\text { do you think } \\
\text { [CELEBRITY] has } \\
\text { about } \\
\text { [CATEGORY]? }\end{array}$ & $\begin{array}{l}\text { 1. Very limited } \\
\text { knowledge } \\
2 . \\
\text { 3. } \\
\text { 4. } \\
\text { 5. Very great knowledge }\end{array}$ & $\begin{array}{l}\text { Adapted from Rossiter } \\
\text { and Smidts (2012) }\end{array}$ \\
\hline
\end{tabular}

\section{Results}

We tested the mediation hypotheses using formal mediation tests (Preacher and Hayes 2008). We also tested the full model (Figure 1) using path analysis based on multiple regression analysis (Pedhazur 1997). In the analyses, the data for the four campaigns were merged. This is in line with previous research in marketing (MacKenzie, Lutz, and Belch 1986) and was supported by Levene's tests showing that there were no significant differences in the variance of the independent variables between the two groups of participants. 
Table 5. Results from mediation analyses (dependent variable: $\mathrm{A}_{\mathrm{BRAND}}$; mediator: $\mathrm{A}_{\text {ENDORSEMENT }}$ ).

\begin{tabular}{lcccccc}
\hline $\begin{array}{l}\text { Independent } \\
\text { variable }\end{array}$ & $\boldsymbol{a}$ path & $\boldsymbol{b}$ path & $\boldsymbol{c}$ path & $\boldsymbol{c}^{\prime}$ path & $\begin{array}{c}\text { Mean } \\
\text { indirect } \\
\text { effect }(\boldsymbol{a} \mathbf{x} \boldsymbol{b})\end{array}$ & $\mathbf{9 5 \%}$ CI \\
\hline $\mathrm{A}_{\text {Celebrity }}$ & $0.55^{* *}$ & $0.32^{* *}$ & $0.18^{*}$ & 0.01 & 0.18 & $\mathrm{~L}=0.08 ; \mathrm{U}=0.29$ \\
Fit & $0.60^{* *}$ & $0.40^{* *}$ & $0.16^{*}$ & -0.08 & 0.24 & $\mathrm{~L}=0.12 ; \mathrm{U}=0.35$ \\
Expertise & $0.37^{* *}$ & $0.29^{* *}$ & $0.22^{* *}$ & 0.12 & 0.11 & $\mathrm{~L}=0.05 ; \mathrm{U}=0.17$ \\
Motive & $0.87^{* *}$ & $0.17^{*}$ & $0.98^{* *}$ & $0.83^{* *}$ & 0.15 & $\mathrm{~L}=0.03 ; \mathrm{U}=0.28$ \\
\hline
\end{tabular}

Notes: CI: confidence interval.

$a$ path: independent variable to mediator.

$b$ path: mediator to dependent variable.

$c$ path: independent variable to dependent variable.

$c^{\prime}$ path: independent variable to dependent variable, controlling for the mediator.

Significance: ${ }^{*} p<0.05 ;{ }^{* *} p<0.01$.

\subsection{Mediation analysis}

We conducted mediation analyses using the procedure and SPSS macro Indirect (Preacher and Hayes 2008). Table 5 reports the regression coefficients for the paths through the mediator, as well as for the direct effect of the independent variable on the dependent variable and the mean indirect effect. The confidence interval for the indirect effect is the equivalent of the Sobel test; if the confidence interval does not include zero, the total mediated effect of the independent variable on the dependent variable is statistically significant at the chosen level (in the current analyses, the chosen level is 95\%).

The results of the mediation analyses with $\mathrm{A}_{\mathrm{BRAND}}$ as the dependent variable (Table 5) lend support to $\mathrm{H} 2 \mathrm{a}-\mathrm{d}$; $\mathrm{A}_{\text {ENDORSEMENT }}$ mediates the effects of $\mathrm{A}_{\mathrm{CELEBRITY}}$ expertise, fit, and perceived motive on $A_{B R A N D}$. Three of the independent variables $-A_{C E L E B R I T Y}$, fit, and expertise - conferred perfect mediation. That is, the mean indirect effect was significant, none of the confidence intervals included zero, and the $c^{\prime}$ paths were not significant. The effect of the remaining variable, motive, on $A_{\text {BRAND }}$ was partially mediated. The mean indirect effect and the $c^{\prime}$ path were significant, in support of partial mediation.

\subsection{Path analysis}

The results of the path analysis appear in Figure 2. The path analysis provides support for all hypothesized relationships except $\mathrm{H} 1 \mathrm{c}$, which posits that perceived celebrity expertise has a positive effect on $A_{B R A N D}$ : All paths in the model were statistically significant, except the path from perceived celebrity expertise to $A_{\text {ENDORSEMENT. }}$ In the mediation analysis, expertise had a significant (mediated) effect on $A_{B R A N D}$. The reason for this difference is that the path analysis is based on multiple regression analysis, which takes into account the effects of all independent variables simultaneously. In the multiple regression analysis, the effect of expertise on $A_{B R A N D}$ was subsumed by one or several of the other independent variables.

The model explained a substantial amount of the variance in $\mathrm{A}_{\text {ENDORSEMENT }}\left(R^{2}=\right.$ $0.58)$. However, the variance explained was lower for $\mathrm{A}_{\mathrm{BRAND}}\left(R^{2}=0.08\right)$. This is not surprising, because multiple factors not included in the model, such as word of mouth and usage experience, can influence $A_{B R A N D}$. 


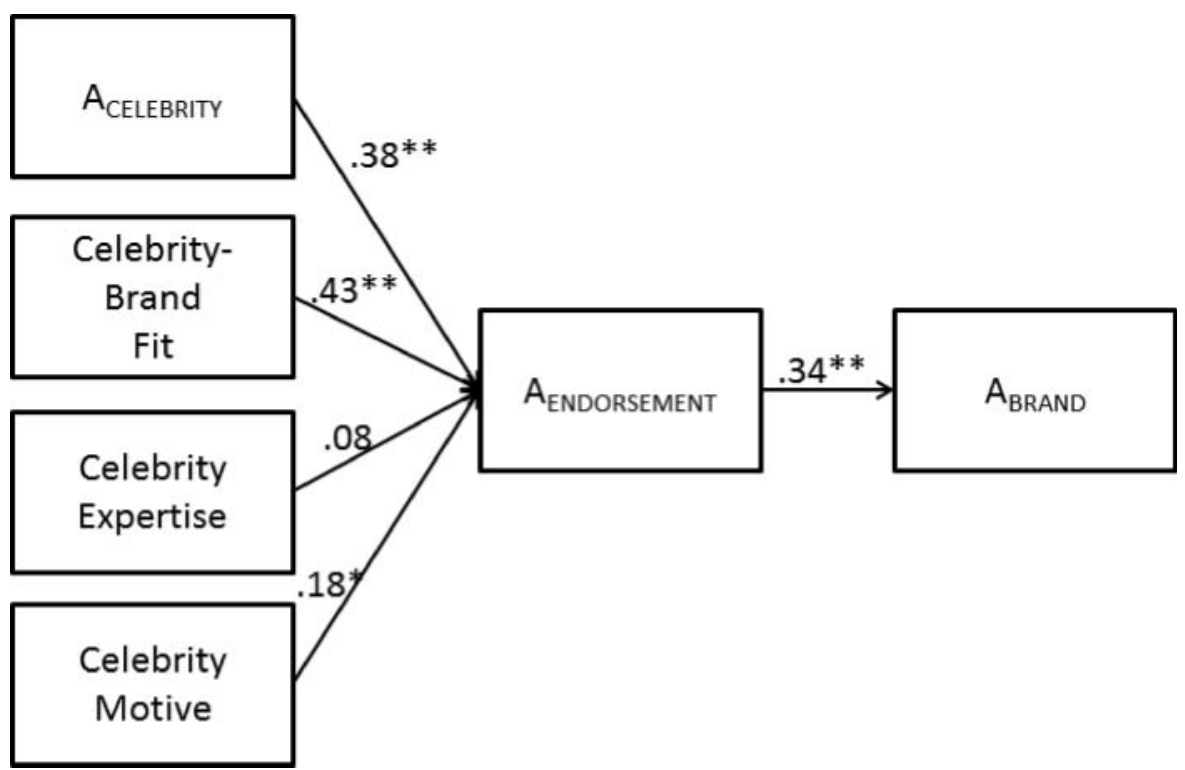

Figure 2. Path analysis of the effects of celebrity and endorsement factors on $A_{\text {BRAND. }}$ Note: ${ }^{*} p<0.05{ }^{* *} p<0.01$.

\section{Discussion}

This study replicates and extends previous research on celebrity endorsements. In line with previous research, the study shows that $\mathrm{A}_{\mathrm{CELEBRITY}}$, expertise, and celebritybrand fit all have positive effects on $A_{B R A N D}$. The study makes two main contributions. The first contribution is the introduction of the mediating variable $A_{\text {ENDORSEMENT; }}$ we show that this variable mediates the effects of commonly used source and endorsement factors on $A_{B R A N D}$. The second contribution is that the study shows that the perceived motive of the celebrity for endorsing the brand has a significant effect on $A_{B R A N D}$, which has not been shown previously. If a celebrity endorser is seen as being motivated not only by money but also by product quality, consumers' brand evaluations will be more positive than if the celebrity is perceived as motivated only by money.

From a theoretical perspective, this study contributes by shedding more light on how celebrity endorsements work. The effects of the celebrity-related factors included herein are fully or partly mediated by $A_{\text {ENDORSEMENT }}$, rather than primarily having direct effects on $A_{B R A N D}$. This suggests that consumers make an overall assessment of a particular endorsement and that it is this assessment, rather than previously studied factors, that directly influences their brand attitudes.

From a research perspective, the introduction of $A_{\text {ENDORSEMENT }}$ should make it easier to disentangle the relative importance of different celebrity factors. $A_{\text {BRAND }}$ is influenced by multiple factors (e.g., past experience with the brand, word of mouth), most of which are not related to the celebrity endorsement, which makes it difficult to establish the relative importance of celebrity-related factors. Fewer factors influence $A_{\text {ENDORSEMENT }}$ than $A_{B R A N D}$, and thus it should be easier to establish which factors have relatively more influence on these constructs.

For marketing managers, the results mean that they can focus on their target audience's A ANDORSEMENT when pre-testing the appropriateness of different celebrity 
endorsers. This should be preferable to choosing one or a few specific factors (e.g., fit, expertise), which may or may not be relevant for the specific brand-celebrity combination, and then relying on the evaluation of these when selecting the celebrity for a campaign. Using attitude towards the endorsement should also make post-campaign evaluations more straightforward and comparable between campaigns than using any of its antecedents.

The present study was based on correlational survey data. While these data offer valuable insights, they do not offer grounds for firm conclusions regarding causal relationships. Thus, it would be of value to replicate the present study in a laboratory experiment with manipulation of the proposed relationships and control of extraneous factors. Moreover, the participants in this study were young and female. Previous studies suggest that a younger target audience may be more susceptible to celebrity endorsement effects (Atkin and Block 1983). Thus, it could be of value to replicate the study with older participants. Studies could also investigate whether there is a wider range of perceived motives than was included in this study, and if including additional motives further increases the explanatory power of the motive variable.

\section{Disclosure statement}

No potential conflict of interest was reported by the authors.

\section{ORCID}

Lars Bergkvist (10 http://orcid.org/0000-0002-4271-9182

\section{References}

Aaker, D.A., and K.L. Keller. 1990. Consumer evaluations of brand extensions. Journal of Marketing 54: 27-41.

Ajzen, I. 1988. Attitudes, personality, and behavior. Buckingham, UK: Open University Press.

Amos, C., G. Holmes, and D. Strutton. 2008. Exploring the relationship between celebrity endorser effects and advertising effectiveness: A quantitative synthesis of effect size. International Journal of Advertising 27, no. 2: 209-34.

Atkin, C., and M. Block. 1983. Effectiveness of celebrity endorsers. Journal of Advertising Research 23: 57-61.

Barone, M.J., A.D. Miyazaki, and K.A. Taylor. 2000. The influence of cause-related marketing on consumer choice: Does one good turn deserve another? Journal of the Academy of Marketing Science 28: 248-62.

Basil, D.Z., and P.M. Herr. 2006. Attitudinal balance and cause-related marketing: An empirical application of balance theory. Journal of Consumer Psychology 16, no. 4: 391-403.

Belch, G.E., and M.A. Belch. 2013. A content analysis study of the use of celebrity endorsers in magazine advertising. International Journal of Advertising 32, no. 3: 369-89.

Bergkvist, L. In press. Appropriate use of single-item measures is here to stay. Marketing Letters. DOI: $10.1007 / \mathrm{s} 11002-014-9325-\mathrm{y}$

Bergkvist, L., and J.R. Rossiter. 2007. The predictive validity of multiple-item versus single-item measures of the same constructs. Journal of Marketing Research 44: 175-84.

Bergkvist, L., and J.R. Rossiter. 2008. The role of ad likability in predicting an ads campaign performance. Journal of Advertising 37: 85-97.

Bergkvist, L., and J.R. Rossiter. 2009. Tailor-made single-item measures of doubly concrete constructs. International Journal of Advertising 28, no. 4: 607-21.

Bush, A.J., C.A. Martin, and V.D. Bush. 2004. Sports celebrity influence on the behavioral intentions of Generation Y. Journal of Advertising Research 44: 108-18. 
Chaiken, S. 1980. Heuristic versus systematic information processing and the use of source versus message cues in persuasion. Journal of Personality and Social Psychology 39, no. 5: 752-66.

Chang, C. 2012. The effectiveness of advertising that leverages sponsorship and cause-related marketing: A contingency model. International Journal of Advertising 31, no. 2: 317-37.

Chattopadhyay, A., and P. Nedungadi. 1992. Does attitude toward the ad endure? The moderating effects of attention and delay. Journal of Consumer Research 19: 26-33.

Choi, S.M., and N.J. Rifon. 2012. It is a match: The impact of congruence between celebrity image and consumer ideal self on endorsement effectiveness. Psychology and Marketing 29: 639-50.

Eagly, A.H., and S. Chaiken. 1993. The psychology of attitudes. Belmont, CA: Wadsworth CENGAGE Learning.

Eisend, M., and T. Langner. 2010. Immediate and delayed advertising effects of celebrity endorsers' attractiveness and expertise. International Journal of Advertising 29, no. 4: 527-46.

Fleck, N., M. Korchia, and I. Le Roy. 2012. Celebrities in advertising: Looking for congruence or likability?. Psychology \& Marketing 29, no. September: 651-62.

Freiden, J.B. 1984. Advertising spokesperson effects: An examination of endorser type and gender on two audiences. Journal of Advertising Research 24: 33-41.

Garcia de los Salmones, M. del Mar, R. Dominguez, and A. Herrero. 2013. Communication using celebrities in the non-profit sector: Determinants of its effectiveness. International Journal of Advertising 32, no. 1: 101-19.

Hovland, C.I., I.L. Janis, and H.H. Kelley. 1953. Communication and persuasion: Psychological studies of opinion change. New Haven: Yale University Press.

Kahle, L.R., and P.M. Homer. 1985. Physical attractiveness of the celebrity endorser: A social adaptation perspective. Journal of Consumer Research 11: 954-61.

Kamins, M.A. 1990. An investigation into the 'match-up' hypothesis in celebrity advertising: When beauty may be only skin deep. Journal of Advertising 19: 4-13.

Kamins, M.A., and K. Gupta. 1994. Congruence between spokesperson and product type: A matchup hypothesis perspective. Psychology \& Marketing 11: 569-86.

Kelley, H.H., and J.L. Michela. 1980. Attribution theory and research. Annual Review of Psychology 59: $457-501$.

Kirmani, A., and B. Shiv. 1998. Effects of source congruity on brand attitudes and beliefs: The moderating role of issue-relevant elaboration. Journal of Consumer Psychology 7, no. 1: $25-47$.

Lafferty, B.A. 2009. Selecting the right cause partners for the right reasons: The role of importance and fit in cause-brand alliances. Psychology \& Marketing 26, no. April: 359-82.

Lafferty, B.A., R.E. Goldsmith, and G.T.M. Hult. 2004. The impact of the alliance on the partners: A look at cause-brand alliances. Psychology \& Marketing 21: 509-31.

Laurent, G. 2013. Respect the data!. International Journal of Research in Marketing 30, no. December: $323-34$.

Lee, J.-G., and E. Thorson. 2008. The impact of celebrity-product incongruence on the effectiveness of product endorsement. Journal of Advertising Research 48, no. September: 433-49.

Luo, L., X. (Jack) Chen, J. Han, and C.W. Park. 2010. Dilution and enhancement of celebrity brands through sequential movie releases. Journal of Marketing Research 47, no. December: 1114-28.

MacKenzie, S.B., R.J. Lutz, and G.E. Belch. 1986. The role of attitude toward the ad as a mediator of advertising effectiveness: A test of competing explanations. Journal of Marketing Research 23: $130-43$.

Malhotra, N.K., S.S. Kim, and A. Patil. 2006. Common method variance in IS research: A comparison of alternative approaches and a reanalysis of past research. Management Science 52: $1865-83$.

Mehta, A. 1994. How advertising response modeling (ARM) can increase ad effectiveness. Journal of Advertising Research 34: 62-74.

Misra, S., and S.E. Beatty. 1990. Celebrity spokesperson and brand congruence. Journal of Business Research 21: 159-73.

Moore, D.J., J.C. Mowen, and R. Reardon. 1994. Multiple sources in advertising appeals: When product endorsers are paid by the advertising sponsor. Journal of the Academy of Marketing Science 22: 234-43.

Nike. 2012. Annual report. Available online at: http://investors.nikeinc.com/files/doc_financials/ AnnualReports/2012/docs/nike-2012-form-10K.pdf (accessed 11 June 2013). 
Ohanian, R. 1990. Construction and validation of a scale to measure celebrity endorsers' perceived expertise, trustworthiness, and attractiveness. Journal of Advertising 19: 39-52.

Ohanian, R. 1991. The impact of celebrity spokespersons' perceived image on consumers' intention to purchase. Journal of Advertising Research 31: 46-54.

Olson, E.L. 2010. Does sponsorship work in the same way in different sponsorship contexts?. European Journal of Marketing 44, no. 1-2: 180-99.

Pedhazur, E.J. 1997. Multiple regression in behavioral research, 3rd ed. Orlando, FL: Harcourt Brace College Publishers.

Podsakoff, P.M., S.B. MacKenzie, J.-Y. Lee, and N.P. Podsakoff. 2003. Common method biases in behavioral research: A critical review of the literature and recommended remedies. Journal of Applied Psychology 88, no. 5: 879-903.

Preacher, K.J., and A.F. Hayes. 2008. Asymptotic and resampling strategies for assessing and comparing indirect effects in multiple mediator models. Behavior Research Methods 40: 879-91.

Ratneshwar, S., and S. Chaiken. 1991. Comprehension's role in persuasion: The case of its moderating effect on the persuasive impact of source cues. Journal of Consumer Research 18: 52-62.

Rossiter, J.R. 2002. The C-OAR-SE procedure for scale development in marketing. International Journal of Research in Marketing 19: 305-35.

Rossiter, J.R. 2011. Measurement for the social sciences: The C-OAR-SE method and why it must replace psychometrics. Berlin: Springer.

Rossiter, J.R. 2012. A new C-OAR-SE-based content-valid and predictively valid measure that distinguishes brand love from brand liking. Marketing Letters 23: 905-16.

Rossiter, J.R., and L. Percy. 1997. Advertising communications \& promotion management, 2 nd ed. New York: McGraw-Hill.

Rossiter, J.R., and A. Smidts. 2012. Print advertising: Celebrity presenters. Journal of Business Research 65: 874-9.

Ruth, J.A., and B.L. Simonin. 2006. The power of numbers: Investigating the impact of event roster size in consumer response to sponsorship. Journal of Advertising 35: 7-20.

Ruth, J.A., and Y. Strizhakova. 2012. And now, goodbye: Consumer response to sponsor exit. International Journal of Advertising 31, no. 1: 39-62.

Schemer, C., J. Matthes,. Wirth, and S. Textor. 2008. Does 'passing the Courvoisier' always pay off? Positive and negative evaluative conditioning effects of brand placements in music videos. Psychology \& Marketing 25: 923-43.

Silvera, D.H., and B. Austad. 2004. Factors predicting the effectiveness of celebrity endorsement advertisements. European Journal of Marketing 38, no. 11/12: 1509-26.

Simmons, C.J., and K.L. Becker-Olsen. 2006. Achieving marketing objectives through social sponsorships. Journal of Marketing 70: 154-69.

Simonin, B.L., and J.A. Ruth. 1998. Is a company known by the company it keeps? Assessing the spillover effects of brand alliances on consumer brand attitudes. Journal of Marketing Research 35: $30-42$.

Speed, R., and P. Thompson. 2000. Determinants of sports sponsorship response. Journal of the Academy of Marketing Science 28: 226-38.

Tripp, C., T.D. Jensen, and L. Carlson. 1994. The effects of multiple product endorsements by celebrities on consumers' attitudes and intentions. Journal of Consumer Research 20: 535-47.

Walchli, S.B. 2007. The effects of between-partner congruity on consumer evaluation of co-branded products. Psychology \& Marketing 24: 947-73.

Wright, P.L. 1973. The cognitive processes mediating acceptance of advertising. Journal of Marketing Research 10: 53-62. 